http://jmscr.igmpublication.org/home/ ISSN (e)-2347-176x ISSN (p) 2455-0450

crossref DOI: https://dx.doi.org/10.18535/jmscr/v7i12.01

\title{
Factors Related to Dental Caries on Elementary School Students in Badung Regency - Indonesia
}

\author{
Authors \\ Asep Arifin Senjaya ${ }^{1 *}$, Ni Made Sirat ${ }^{2}$, I Nyoman Wirata ${ }^{3}$ \\ ${ }^{1,2,3}$ Department of Dental Health, Health Polytechnic of Health Ministry Denpasar, Indonesia \\ *Corresponding Author \\ Asep Arifin Senjaya
}

\begin{abstract}
Caries, dental and oral disease affects $90 \%$ of school-age children. Badung regency occupied fourth position of the populations with dental problem in past 12 months. The data shows only $3.6 \%$ of Badung population who behaved properly in brushing. Badung regency economically has the highest local revenues in Bali. The objective of this research is to understand the factors associated with dental caries in primary school students in Badung. This research type is quantitative- qualitative, conducted from July to September 2016. The sample was 252 students, selected by multistage random sampling. The result showed $71 \%$ of students belong to very high, high, and moderate caries; $64.8 \%$ of students belongs to low sosio-economic category and $89.7 \%$ of students need guidance in brushing. The results show there is no relationship between the variables of socio-economic category with a classification of dental caries proven by sig value results in 0.552. There is a relationship between variables of behavior criteria in brushing with dental caries classification with sig. value of 0.000. There is a relationship between school dental health (UKGS) with the classification of dental caries with sig. value of 0.001. Multivariate analysis shows sub variable UKGS category 1 and sub variable category 2 are associated with dental caries.

Keywords: Behaviour, children, dental caries, factors; related.
\end{abstract}

\section{Introduction}

The degree of health of a person or community is influenced by four factors: environment, attitudes, hereditary, and health care ${ }^{1}$. There are three factors affecting one's behaviour, predisposition factors, supporting factors, and reinforcing factors ${ }^{2}$. Oral health is a fundamental part of general health and welfare of life. Oral health disorder will have an impact on one's performance. ${ }^{3}$

Dental caries is a dental and oral disease that is widely suffered by $90 \%$ of school-age children. Caries is also the cause of primary pathology of decayed tooth that occur due to the lack of child care and parental knowledge ${ }^{4}$. Parents need to observe and regularly record changes occurring at the child's oral cavity in anticipation of early dental disorders and abnormalities, such as dental caries. ${ }^{5}$ The average caries experience (DMF-T) of 12 years old children ranged from 2.4. The DMF-T index according to WHO for school-age children up to 12 years is $\leq 3^{6}$. School-age children are one of the groups that are vulnerable to caries, as they generally still have a lack of knowledge and behavior that is lacking in dental caries.

There has been an increase in the prevalence of active dental caries in Indonesian population compared to 2007 years ago, namely from 43.4 in 
2007 to $53.2 \%$ in 2013. More than 93 million Indonesian people suffer from active caries. People with dental and oral problems in past 12 months in Badung

Regency is at the top four in the province of Bali, which is $31.6 \%^{7}$. Plaque that is firmly attached to the surface of the tooth and gums may cause disease in the hard tooth tissue and its supporting tissues ${ }^{8}$.

Riskesdas Data 2013 shows the percentage of the population aged 10 and above who brush their teeth every day in Badung Regency was $94.2 \%$ and only $3.6 \%$ that behaved properly in brushing ${ }^{7}$.Parents ' participation is indispensable in guiding, caring, understanding, reminding, and providing facilities for children to keep their teeth clean ${ }^{9}$

Parents have an enormous influence on child behavior, as parents are the first figure to their children. Parents are obligated to give and teach positive things as well as compassion. ${ }^{9}$

Dental health services in Health Centre (Puskesmas) can be implemented in and outside the building such as School Dental Health (UKGS) and in Posyandu (Integrated Health Post ${ }^{10}$. School Dental Health consists of three stages, namely UKGS phase I, UKGS phase II, and UKGS phase III ${ }^{11}$.

Badung Regency has the largest economic scale in Bali, in terms of regional revenues and expenditure (APBD). This can be understood because the Badung Regency has the famous tourist destinations ${ }^{12}$. The revenue distribution of Bali province in 2013 shows $40 \%$ middle-ranking society covers $15.12 \%$ of Badung Regency. Badung Regency is second population with low income after the city of Denpasar ${ }^{13}$.

Furthermore, the problem can be formulated with "What is the relation of factors with dental caries in elementary school students in Badung Regency in 2016?"

The purpose is to understand the factors related to dental caries of elementary school students in Badung Regency in 2016.

\section{Method}

This research uses quantitative and qualitative method. The research took place in elementary schools (SD) class six, in six sub-districts in Badung Regency, namely: SDN 3 Kuta; SDN 11 Jimbaran; SDN 1 Kerobokan; SDN 1 Pangsan; SDN 2 medium; SDN 3 Sempidi. Data collection and information was done from July to September 2016. The research population is all elementary school students and their parents in Badung Regency. Large sample research is taken with a large formula of cross sectional study ${ }^{14}$. In this study the number of samples was reproduced, taken 42 students in each SD, so the total number of 252 students and 252 parents, taken with multistage random sampling. The FGD informant was from the representatives of the parents, each of the elementary school parents (mothers) of students are ten in number. The indepth interview informant was a teacher in each of the elected primary schools. Dental caries data is measured by direct examination, tooth brushing with interview and observation, socio-economics using questionnaire, UKGS with interview. While the perception of parents and teachers about dental caries was acquired through FGD and in-depth interview.

Quantitative data analysis was done using univariate, frequency and percentage. Bivariate analysis with cross-tabulation and correlation test Spearmen in multivariate analyses used multi-regression logistics. Qualitative information obtained was used to complement quantitative discussions.

\section{Result and Discussion}

School-age children are one of the groups vulnerable to caries, as they still have less knowledge and behaviour against dental caries ${ }^{15}$. Table 1 shows the frequency distribution of students based on caries they suffer from.

Table 1 Student frequency distribution based on dental caries classification

\begin{tabular}{|l|c|}
\hline $\begin{array}{l}\text { Classification of } \\
\text { Dental Caries }\end{array}$ & $\mathbf{f ( \% )}$ \\
\hline Very high & $74(29,4)$ \\
\hline high & $53(21,0)$ \\
\hline moderate & $52(20,6)$ \\
\hline low & $20(7,9)$ \\
\hline Very low & $53(21,0)$ \\
\hline Total & $252(100)$ \\
\hline
\end{tabular}


Table 2 shows 164 students $(64.8 \%)$ included in the low socioeconomic category (average income under Rp. 1,500,000.- / month) and moderate (average income from $\mathrm{Rp}$

Rp 1,500,000. - to Rp. 2,500,000.- / month), the remaining $34.9 \%$ is categorized as high and very high socioeconomic. Based on this data it can be said that most students are poor families. The most influential factor on health according to ${ }^{1}$ is the environment. Within these environmental factors, the economy is a part of it. The environment, including socioeconomic, has the greatest role in health. Many studies show that the prevalence of caries is higher in children who come from low socioeconomic status.
Table 2 Frequency distribution by socio-economic category

\begin{tabular}{|l|c|}
\hline Socio-economic category & $\mathbf{f ( \% )}$ \\
\hline Low & $51(20,0)$ \\
\hline Moderate & $113(44,8)$ \\
\hline High & $56(22,2)$ \\
\hline Very high & $32(12,7)$ \\
\hline Total & $252(100)$ \\
\hline
\end{tabular}

Table 3 shows 226 students $(89.7 \%)$ need guidance in brushing their teeth. Only 2 students had excellent tooth brushing behaviour and 3 students had good tooth brushing behavior. This data is in accordance with the results of Basic Health Research in $2013^{7}$, where in the population in Badung Regency $94.2 \%$ brushed teeth every day, but only $3.6 \%$ behaved correctly in brushing.

Table 3 Frequency distribution by socio-economic category

\begin{tabular}{|l|c|c|c|c|c|c|c|}
\hline No. & \multirow{2}{*}{$\begin{array}{c}\text { Age } \\
\text { Group }\end{array}$} & \multicolumn{2}{|c|}{ Intervention Group } & \multicolumn{2}{c|}{ Sample Control Group } & \multicolumn{2}{|c|}{ Total } \\
\cline { 3 - 8 } & $\mathrm{f}$ & $\%$ & $\mathrm{f}$ & $\%$ & $\mathrm{f}$ & $\%$ \\
\hline $\mathbf{1 .}$ & 8 & 64 & 51.6 & 60 & 48,4 & 124 & 50 \\
\hline $\mathbf{2 .}$ & 8,5 & 1 & 8 & - & - & 1 & 0,4 \\
\hline 3. & 9 & 53 & 42.7 & 63 & 50,8 & 116 & 46.8 \\
\hline 4. & 10 & 6 & 4,9 & 1 & 0.8 & 7 & 2.8 \\
\hline \multicolumn{2}{r}{ Total } & 124 & 100 & 124 & 100 & 248 & 100 \\
\hline
\end{tabular}

All informants said that if a tooth has a cavity, it must be treated immediately, that is, it is patched to the dentist, not to cause pain / swelling. But if it cannot be treated it should be removed and made denture.

The role of parents, especially a mother in maintaining dental health is very important in underlying the formation of behaviors that support children's dental hygiene so that children's dental health can be maintained properly ${ }^{16}$.

Most of the informants said that they should remind their children to brush their teeth. A small number of informants said not always, some informants even said that it was rare and

some said that they did not remind again with the reason that they were bored, because as if the words of their parents were ignored, the children preferred to play mobile phones / games rather than being told to brush their teeth. But actually, all the informants agreed that parents should not be bored and must continue to remind their children to brush their teeth until the child has a habit of being independent in brushing teeth.
The study found inactive UKGS in SDN 1 Pangsan, SDN 3 Sempidi in UKGS Phase I, and four other SDNs namely: SDN 11 Jimbaran, SDN 3 Kuta, SDN 1 Kerobokan, and SDN 2 Sedang, the UKGS was less active. The results of this study are similar to the conclusions of a study conducted by ${ }^{17}$ which stated that the UKGS program in the Polonia Puskesmas's work area was not maximal. Dental health services can be carried out in or outside Puskesmas such as the School Dental Health Efforts (UKGS) at schools and at Posyandu. Puskesmas have an important role in the implementation of the UKGS program ${ }^{11}$.

The implementation of the UKGS involved a number of staff, from Puskesmas namely dentists and dental nurses, while the implementers from the schools were health sports teachers. The attitude of the health sports teacher towards the UKGS program is very influential on the changes in students' attitudes to oral health and the success of this program ${ }^{10}$.

The cross table between the socioeconomic categories and the classification of dental caries 
presented in table 4 , does not show a certain trend. Table 4 shows the spearman correlation test between socioeconomic categories of variables with the classification of dental caries with the result of sig. 0.552. A sig value $>0.05$ means that there is no relationship between socioeconomic categories of variables and dental caries classification. There is no influence on the socioeconomic level of parents on dental caries of children ${ }^{18}$. Besides, no significant relationship significant from the proportion of the caries status of the respondent with the income of the respondent's parents ${ }^{19}$.

Table 4 Cross tabulation of socio-economic category with dental caries classification

\begin{tabular}{|l|c|c|c|c|c|}
\hline \multirow{2}{*}{$\begin{array}{l}\text { Classification of } \\
\text { dental caries }\end{array}$} & \multicolumn{4}{|c|}{ Socio-economic category } & \multirow{2}{*}{ Total (\%) } \\
\cline { 2 - 5 } & $\begin{array}{c}\text { Low } \\
\mathbf{n}(\%)\end{array}$ & $\begin{array}{c}\text { Moderate } \\
\mathbf{n}(\%)\end{array}$ & $\begin{array}{c}\text { High } \\
\mathbf{n}(\%)\end{array}$ & Very High n(\%) & \\
\hline Very high & $14(19,0)$ & $32(43,2)$ & $18(24,3)$ & $10(13,5)$ & $74(100)$ \\
\hline high & $11(20,8)$ & $29(54,7)$ & $10(18,9)$ & $3(5,6)$ & $53(100)$ \\
\hline moderate & $15(28,8)$ & $22(42,3)$ & $7(13,5)$ & $8(15,4)$ & $52(100)$ \\
\hline low & $2(10)$ & $7(35)$ & $6(30)$ & $5(25)$ & $20(100)$ \\
\hline Very low & $9(17,0)$ & $23(43,4)$ & $15(28,3)$ & $6(12,7)$ & $53(100)$ \\
\hline Total & $51(20,3)$ & $113(44,8)$ & $56(22,2)$ & $32(12,7)$ & $252(100)$ \\
\hline
\end{tabular}

The cross tabulation between the criteria for tooth brushing behavior with the classification of dental caries presented in Table 5, shows the tendency of the better behavior, the lower the caries. This is proven by the Spearman correlation test between the behavioral brushing criterion variables with the classification of dental caries with the result of sig. 0,000 and the correlation coefficient (r) 0.203. Sig value $<0.05$ means that there is a relationship between the variable brushing behavior criteria with the classification of dental caries with a weak relationship strength.

Table 5 Cross tabulation criteria with dental caries classification

\begin{tabular}{|l|c|c|c|c|c|}
\hline \multirow{2}{*}{$\begin{array}{l}\text { Classification of } \\
\text { dental caries }\end{array}$} & \multicolumn{3}{|c|}{ Socio-economic category } & \multirow{2}{*}{ Total (\%) } \\
\cline { 2 - 5 } & $\begin{array}{c}\text { Need guidance } \\
\mathbf{n}(\%)\end{array}$ & $\begin{array}{c}\text { Moderately } \\
\mathbf{n}(\%)\end{array}$ & Good $\mathbf{n}(\%)$ & $\begin{array}{c}\text { Very good } \\
\mathbf{n}(\%)\end{array}$ & \\
\hline Very high & $\mathbf{7 3 ( 9 8 , 6 )}$ & $1(1,4)$ & $0(0)$ & $0(0)$ & $74(100)$ \\
\hline high & $49(92,5)$ & $4(7,5)$ & $0(0)$ & $0(0)$ & $53(100)$ \\
\hline moderate & $43(82,7)$ & $6(11,5)$ & $2(3,8)$ & $1(1,9)$ & $52(100)$ \\
\hline low & $16(80)$ & $3(15)$ & $1(5)$ & $0(0)$ & $20(100)$ \\
\hline Very low & $45(89,9)$ & $7(13,2)$ & $0(0)$ & $1(1,9)$ & $53(100)$ \\
\hline Total & $226(89,7)$ & $21(8,3)$ & $3(1,2)$ & $2(0,8)$ & $252(100)$ \\
\hline
\end{tabular}

The conclusions of (Anitasari and Rahayu) ${ }^{18}$ states that there is a correlation between the frequency of tooth brushing and the level of dental and oral hygiene. Table 6 shows the better implementation of the UKGS, the higher the caries rate. Spearmen correlation test between UKGS category variables and dental caries classification obtained sig. 0.001 and the correlation coefficient (r) -0.252. This means that there is a relationship between the two variables with the strength of the weak relationship in the opposite direction. The results of this study are different from the results of research conducted previously where students in primary schools who did not carry out UKGS program have a higher risk of caries exposure compared to students in primary schools who receive the UKGS program ${ }^{20}$.

Table 6 Cross tabulation category UKGS with dental caries classification

\begin{tabular}{|l|c|c|c|c|}
\hline \multirow{2}{*}{$\begin{array}{l}\text { Classification of } \\
\text { dental caries }\end{array}$} & \multicolumn{3}{|c|}{ UKGS category } & \multirow{2}{*}{ Total (\%) } \\
\cline { 2 - 5 } Very high & No UKGS n(\%) & UKGS Inactive n(\%) & UKGS Phase I n(\%) & \\
\hline High & $7(9,5)$ & $47(63,5)$ & $\mathbf{2 0}(\mathbf{2 7 , 0 )}$ & $74(100)$ \\
\hline Moderate & $10(18,8)$ & $31(58,5)$ & $12(22,7)$ & $53(100)$ \\
\hline Low & $9(17,3)$ & $34(65,4)$ & $9(17,3)$ & $52(100)$ \\
\hline Very low & $3(15)$ & $17(85)$ & $0(0)$ & $20(100)$ \\
\hline Total & $\mathbf{1 3 ( 2 4 , 5 )}$ & $39(73,6)$ & $1(1,9)$ & $53(100)$ \\
\hline
\end{tabular}




\section{JMSCR Vol||07||Issue||12||Page 01-07||December}

Table 7 shows SDN 3 Sempidi (UKGS Phase I category) having the most students who need guidance on brushing and none of their students behave well and very well. This factor may have contributed to the high caries in SDN 3 Sempidi. Though they are in the UKGS Phase I category, their teeth brushing behaviour is bad. Unlike the case with SDN 1 Pangsan, although in SDN 1 Pangsan there was no UKGS, but his teeth-brushing behaviour was generally the best, there were found two students with excellent tooth-brushing behaviour. In (Suryani) ${ }^{20}$ shows that the scope of UKGS program had not met the target. The supervision and control of UKGS program does not yet have clear indicators. Supervision is only carried out by a small proportion of Puskesmas. Lack of guidance and supervision at the level of district and unclear UKGS structure at the provincial level. This is also possible in Badung District, which has an impact on outputs that are not as expected.

In addition, caries etiology is very much, not only from UKGS program. The internal factors are directly related, consisting of four factors, namely the host (teeth and saliva), the causative agent of the disease (microorganisms in plaque), the substrate (carbohydrate), and the time. External factors include factors such as age, ethnicity, culture, social population, awareness, attitudes, and behaviour of individuals towards dental health.

Table 7 Elementary tabulation with dental behaviour

\begin{tabular}{|l|c|c|c|c|c|}
\hline \multirow{2}{*}{ Elementary School } & \multicolumn{3}{|c|}{ Dental Brushing Behavior } & \multirow{2}{*}{ Total } \\
\cline { 2 - 5 } & $\begin{array}{c}\text { Need } \\
\text { guidance. }\end{array}$ & Moderate & Good & Very good & \\
\hline SDN 11 Jinbaran & 39 & 3 & 0 & 0 & 42 \\
\hline SDN 3 Kuta & 37 & 5 & 0 & 0 & 42 \\
\hline SDN 1 Kerobokan & 39 & 3 & 0 & 0 & 42 \\
\hline SDN 3 Sempidi & 41 & 1 & 0 & 0 & 42 \\
\hline SDN 2 Sedang & 37 & 4 & 1 & 0 & 42 \\
\hline SDN 1 Pangsan & 33 & 5 & 2 & 2 & 42 \\
\hline
\end{tabular}

Table 8 shows logistic regression multivariate test results of UKGS variable and tooth brushing behavior variable that were simultaneously tested with dental caries variable, showing the results of the UKGS sub variable category 1 (UKGS not active / no UKGS) (sig. 0.001) and the UKGS sub variable category 2 (UKGS less active / there is a UKGS but not Phase I) (sig. 0,000). The results of this test can be interpreted if the UKGS variable and the variable brushing behaviour are simultaneously tested with dental caries variable, then UKGS sub variable category 1 (UKGS is inactive / no UKGS) and the UKGS sub variable category 2 (UKGS is less active / there is UKGS but not Phase I) associated with dental caries. This can be understood even though SDN 3 Sempidi is included in the UKGS category 3 (UKGS Phase I), but because almost all respondents way of brushing still need guidance and other factors not examined in this study, which may be a cause of high caries in SDN 3 Sempidi So that in this study UKGS seems not useful in preventing dental caries.

Table 8 Test results Multivariate Logistic regression

\begin{tabular}{|c|c|c|c|c|c|c|c|c|}
\hline & & \multirow[t]{2}{*}{ Estimate } & \multirow{2}{*}{$\begin{array}{c}\text { Std. } \\
\text { Error }\end{array}$} & \multirow[t]{2}{*}{ Wald } & \multirow[t]{2}{*}{ df } & \multirow[t]{2}{*}{ Sig. } & \multicolumn{2}{|c|}{ 95\% Confidence Interval } \\
\hline & & & & & & & Lower Bound & Upper Bound \\
\hline \multirow[t]{7}{*}{ Loc } & {$[\mathrm{ukgs}=1]$} & 1.409 & .415 & 11.538 & 1 & .001 & .596 & 2.222 \\
\hline & {$[\mathrm{ukgs}=2]$} & 1.161 & .327 & 12.607 & 1 & .000 & .520 & 1.802 \\
\hline & {$[\mathrm{ukgs}=3]$} & $0(\mathrm{a})$ & & 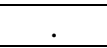 & 0 & . & $\dot{\varphi}$ &. \\
\hline & [brus $=1]$ & -1.257 & 1.370 & .842 & 1 & .359 & -3.941 & 1.428 \\
\hline & [brus =2] & -.229 & 1.415 & .026 & 1 & .872 & -3.002 & 2.545 \\
\hline & [brus $=3]$ & -.743 & 1.692 & .193 & 1 & .661 & -4.060 & 2.575 \\
\hline & [brus $=4]$ & $0(\mathrm{a})$ & 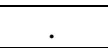 & . & 0 & . & . & . \\
\hline
\end{tabular}




\section{Conclusions}

Most students of SDN in Badung Regency have dental caries with classification of high and very high caries. They come from moderate and low socio-economics and need guidance of brushing their teeth. Most of the UKGS at SDN in Badung Regency are inactive categories. Regarding socieeconomic and dental caries on students at SDN Kabupaten Badung, there is no relation between those variables but there is a relationship between brushing and dental caries on students at SDN Kabupaten Badung as well as there is a relationship between UKGS and dental caries on students at SDN Kabupaten Badung. Either inactive or less active UKGS, they have relation to dental caries on students at SDN Kabupaten Badung. Qualitative study concluded that parents of students and sports teachers have a good knowledge and attitude about dental caries.

\section{Acknowledgement}

Obtained from the Committee of Respondents agreement. Source of Funding: Ministry of Health Republic Indonesia.

\section{References}

1. Notoatmodjo, S. Education and health behavior. Jakarta: Rineka Cipta. 2003

2. Sriyono, NW. Preventing dental and oral diseases in order to improve quality of life, speeches of the inaugural Department of the Faculty of Dentistry at Universitas Gadjah Mada Yogyakarta. 2009.

3. Putri MH, Herijulianti E, Nurjanah N. The science of disease prevention hard Network and dental support network,Jakarta: EGC. 2011.

4. Itjingningsih W H. Anatomi Gigi. Jakarta: EGC. 1991.

5. World Health Organization (WHO). Oral Health Information Systems. 2003. Available at: www.who.int/oral health/action/information. Accessed January 19, 2016.
6. Ministry of Health (Depkes) RI. How to work with dental and oral health care in Puskesmas. Jakarta: Directorate of Dental Hygiene. 1995.

7. Suciari A, Arief YS, Rachmawati PD. Parents role in guiding teeth brushing with the genesis of preschool children's dental caries. 2015. Available at: journal.unair.ac.id/download-fullpaperspmnj5ab2f12. Retrieved: 18 January 2016.

8. Puspitoningsih N, Safitri W, Istiningtyas A. Mother's perception of dental caries in preschool-age children in TK Darma Women's District Kemusu Boyolali. 2015. Available at www.digilib.stikeskusumahusada.ac.id. Retrieved: 18 January 2016.

9. Ministry of Health () RI. Dental and oral helath care guidelines (UKGS). Jakarta: Directorate General of Bina Kesehatan Health. 2012.

10. Septiasih. Badung has the largest economic scale in Bali. 2015. Available at https://www.selasar.com. Retrieved 20 January 2016.

11. Central statistic Agency (BPS). Bali in numbers 2014. Available at: Bali bps.go.id. Accessed in 18 January 2016.

12. Murti B. Principles and methods of epidemiology research. Yogyakarta: Gadjah Mada University Press. 1997

13. World Health Organization (WHO). Oral Health Surveys Basic Methods - 5th edition. 2013. Available at: www.who.int/oralhealth/publication. Retrieved 20 January 2016.

14. Suwelo I S. Dental caries in children with a variety of etiology factors: study on preschool age children. Jakarta: EGC. 1992.

15. Tunggadewi G. Analysis of the implementation of Dental Health Business Program (UKGS) in the region of Polonia district of Medan Polonia in 2014. Thesis. 2015. Available at:www.digilib.usu.ac.id. Accessed: 18 Jan 2016. 
16. Ngangtung R, Pangemanan HC, Gunawan PN. Influence of the social eonomic level of parents to children's caries in the TK Hang Tuah Bitung. 2015. Available at: E-Dental Journal (eG) Volume 3, Number 2, JulyDecember 2,015,542. Accesed 18 January 2016.

17. Susi, Bachtiar H, Azmi U. Relationship of the elderly socio-economic status with caries on the eldest teeth of children aged 4 and 5 years. Andalas Medical Magazine No. 1. Vol.36. January 2012. Available at: jurnalmka,fk, unand.ac.id/index.php/article. Accessed 18 January 2016.

18. Anitasari S, Rahayu N E. Relations frequency brushing with dental hygiene and mouth level students of public elementary school in District Palaran Samarinda Municipality of East Kalimantan Province. Dentistry magazine. (Dental Journal), Vol. 38. 2 April - June 2005:88 - 90. Available at : journal.unair.ac.id. Retrieved 18 October 2016.

19. Kamayanti I A, Tauchid S N, Harahap N N. Risk difference in the occurrence of new caries in children aged 12 years of elementary school students of UKGS and SD non UKGS in the district of Cilandak South Jakarta in 2011. Research report. Available at: poltekkesjakarta.ac.id/file/dokumen. Retrieved 20 January 2016.

20. Suryani Y. Analysis of the management of dental health business Program at the Healthcenter of the school of Jakarta Barat year 2002. Thesis. Available at: http://lib.ui.ac.id/bo/uibo. Accessed 19 January 2016. 